\title{
MEMBANGUN JEMBATAN ANTARA BUKU DAN PRAKSIS ARSITEKTUR
}

\author{
Abraham Mohammad Ridjal \\ Jurusan Arsitektur Universitas Brawijaya \\ Email:amridjal@gmail.com
}

\begin{abstract}
ABSTRAK
Berbagai anggapan sering muncul terkait hubungan antara dunia akademis dan dunia praktek arsitektur yang mengatakan keduanya saling bertolak belakang dan berbeda arah. Dunia akademisi dianggap sebagai dunia dimana calon arsitek bebas berkreasi dengan angan-angan dan impian yang tidak terbatas, sedangkan dunia ppraktek adalah dunia dimana banyak aturan dan batasan-batasan yang mengekang ide kreatifitas, karena banyak tuntutan yang harus dipenuhi. Padahal jika menilik proses awal lahirnya ilmu arsitektur, tidak ada dikotomi antara dunia arsitektur dan dunia praksis, keduanya tidak terpisahkan. Keilmuan arsitektur akan didapatkan ketika kita berpraktik di lapangan, demikian juga pengembangan praksis keilmuan akan menjadi lebih tajam setelah kita banyak melakukan pengamatan dan penyimpulan terhadap proses ber-arsitektur, sebagaimana wujud arsitektur tradisional kita. Metode semacam ini merupakan proses induktif, dimana kita menyimpulkan pengamatan-pengamatan yang kita lakukan di lapangan untuk dirumuskan menjadi sebuah kajian keilmuan. Dengan demikian, pendidikan dan pengajaran arsitektur akan dapat memperkecil ketidakpastian (anomali).

Melalui penggalian lebih dalam mengenai keterkaitan antara proses yang dilakukan oleh para praktisi dengan pengajaran yang dilakukan dalam dunia pendidikan arsitektur agar dapat terbangun sinergi diantara keduanya. Selain itu, sebagai pengembangan teori dan pengajaran arsitektur, juga perlu dirumuskan konsep desain yang berangkat dari pengalaman praksis untuk memperkaya teori yang sudah dikembangkan di dunia kampus
\end{abstract}

Kata Kunci: praksis arsitektur, akademisi, metode desain, pengalaman berarsitektur

\section{Pendahuluan}

\subsection{Sejarah Pendidikan Arsitektur}

Kata 'arsitektur' berasal dari kata Yunani 'arche' yang berarti ketua dan 'tektoon' berarti pembangun atau tukang kayu. 'Archetektoon' bisa diartikan sebagai kepala tukang atau orang yang ahli dalam membangun. Kata arsitektur dalam bahasa Yunani berarti hasil karya seorang kepala tukang. Dalam kamus Oxford, arsitektur berarti seni dan ilmu dalam merancang bangunan. Dalam pengertian di atas, arsitektur hanya diartikan sebagai bangunan atau proses yang berkaitan dengan bangunan. Sedangkan jika dilihat lebih luas, arsitektur tidak hanya berhubungan dengan bangunan saja, namun mencakup keseluruhan kegiatan membangun sebuah lingkungan binaan, mulai dari skala makro seperti lansekap dan perancangan kota sampai pada skala mikro seperti desain produk dan perabot. 
Jika menilik dari pengertian arsitektur secara luas, ruang lingkup dan kajian dalam bidang arsitektur selalu berkaitan dengan multi disiplin keilmuan. Oleh karena itu, dalam melihat dunia arsitektur tidak bisa hanya dengan sebelah mata, atau dengan paradigma tertentu saja, karena kesemuanya terkait satu sama lain. Pada awal perkembangan metode penyampaian keilmuan arsitektur, Alexander (1964) menjelaskan bahwa praktisi arsitektur memiliki keterkaitan dengan para pendahulunya, apa yang dipelajari dan dipahami dalam keilmuan arsitektur diperoleh melalui 'immitation and correction', dengan demikian transfer pengetahuan dapat diperoleh melalui pengalaman pragmatis. Demikian juga ketika kita ingin membangun sebuah rumah pada masa lalu, kita juga harus terlebih dahulu melihat secara langsung bagaimana rumah dibangun, sehingga kita bisa meniru hal yang sama.

Perkembangan ilmu arsitektur telah merubah proses transfer keilmuan dari pemagangan murni menjadi kombinasi antara penyampaian materi dalam kelas dengan pemagangan atau pengamatan terhadap objek/ subjek yang beraktifitas dalam dunia arsitektur. Metode pengajaran 'teori' yang diajarkan dalam kelas seperti sejarah arsitektur, metode perancangan, dan lainnya dikombinasikan dengan pengajaran keterampilan perancangan arsitektur yang disampaikan dalam studio yang merepresentasikan metode pemagangan.

Perkembangan pendidikan arsitektur atau 'merancang arsitektur' secara garis besar dapat digolongkan menjadi 3 (tiga) kategori, yang dimulai dari "meniru dan mengoreksi" yang dijelaskan oleh Alexander (1964) bahwa immitation and correction merupakan taktik untuk memahami proses intuisi yang dapat dipelajari melalaui sebuah karya seni. Selanjutnya disusul dengan "sistem magang" yang dilakukan oleh beberapa calon arsitek dalam menimba keilmuan arsitektur melalui pengalaman para 'pakar' dalam dunia praksis arsitektur. Langkah ini pernah ditempuh oleh Frank Lloyd Wright ketika magang di kantor "Sullivan \& Adler", Chicago, Amerika (Handinoto, 2008). Selanjutnya berkembang menjadi "sistem studio" yang sampai saat ini masih dipandang sebagai sistem pembelajaran arsitektur yang terbaik.

Jika ditilik dari awal munculnya pendidikan arsitektur di Indonesia, ITB merupakan sekolah pertama dimana diajarkan pendidikan arsitektur didalamnya. ITB yang didirikan pada 1920 dengan nama "Technische Hooge School (THS)" ini merupakan turunan dari pendidikan yang berkembang di Eropa, termasuk arsitekturnya. Oleh karena itu, untuk merujuk system pengajaran yang berkembang di ITB ini, hendaknya menelusuri terlebih dahulu sumber dari munculnya keilmuan arsitektur di Eropa sebagai cikal bakal pendidikan arsitektur di Indonesia.

\subsection{Hubungan Dunia Akademis dengan Dunia Praktek Arsitektur}

Keterkaitan antara dunia akademis (kampus) dengan dunia profesi (praktek) merupakan dua kutub berbeda yang saling bergantung antara satu dengan lainnya. Dengan kata lain, bisa dijabarkan bahwa kampus merupakan sumber munculnya tenaga ahli yang menggerakkan roda keprofesian arsitektur, sedangkan dunia praktek merupakan tujuan dari dibentuknya pendidikan arsitektur di kampus.

Pembelajaran tentang arsitektur tidak hanya dimulai dari munculnya pendidikan arsitektur resmi pertama kalinya, akan tetapi sejak pertama manusia mendiami bumi ini sudah melakukan proses pembelajaran arsitektur. Seperti yang diungkapkan oleh Rapoport (1969), bahwa arsitektur semula lahir untuk menciptakan tempat tinggal sebagai wadah untuk perlindungan manusia dari gangguan lingkungan; alam dan binatang. Kemudian Crowe (1995) melanjutkan dengan menjelaskan bahwa bentuk dan fungsi bangunan adalah respon yang diberikan oleh manusia dalam interaksinya dengan lingkungan sekitarnya. Dalam hal ini pembelajaran langsung telah dilakukan antara manusia terhadap alam, untuk kemudian diwujdukan melalui kegiatan ber-arsitektur. Dengan demikian, pada dasarnya memang tidak bisa dipisahkan antara proses pembelajaran dengan proses praksis, karena keduanya selalu muncul secara bersamaan dan saling berkait antara satu dengan lainnya. 
Jika berbicara mengenai dunia akademis dan dunia praktek dalam arsitektur, Vitruvius pernah berkata: "Praktek dan teori adalah akar arsitektur". Pengertian praktek adalah perenungan yang berkelanjutan terhadap pelaksanaan sebuah proyek atau pengerjaannya dengan tangan, dalam proses konversi bahan bangunan dengan cara yang terbaik. Sedangkan teori adalah hasil pemikiran beralasan yang menjelaskan proses konversi bahan bangunan menjadi hasil akhir sebagai jawaban terhadap suatu persoalan. Seorang arsitek yang berpraktek tanpa dasar teori tidak dapat menjelaskan alasan dan dasar mengenai bentuk-bentuk yang dia pilih. Sementara arsitek yang berteori tanpa berpraktek hanya berpegang kepada "bayangan" dan bukannya substansi. Seorang arsitek yang berpegang pada teori dan praktek, ia memiliki senjata ganda. Ia dapat membuktikan kebenaran hasil rancangannya dan juga dapat mewujudkannya dalam pelaksanaan.

Untuk dapat melihat keterkaitan secara langsung antara dunia akademis dengan dunia praktek dalam arsitektur, Rem Koolhas telah menjadikan dirinya sebagai bridging yang patut diteladani. Profesi sebagai arsitek ditekuninya sejak tahun 1975 bersama Office of Metropolitan Architecture (OMA), disamping itu beliau juga menyempatkan dirinya untuk mengisi kuliah arsitektur di Harvard University, sampai mendapatkan penghargaan sebagai professor disana. Dalam hal ini, beliau tidak melupakan dunia akademisi ketika mulai berprofesi sebagai arsitek, bahkan bahan jkajian dan galian keilmuannya dalam dunia kampus dikembangkan secara riil ketika harus beraktifitas sebagai seorang arsitek. Hal ini justru membuat karya-karyanya semakin bernilai dan memiliki esensi yang kuat. Di dalam negeri kita juga punya Ridwan Kamil, yang bergerak dalam bidang arsitektur bersama Urbane (yang mengkhususkan diri pada bidang Urban Design/Planning Consultant) pada tahun 2003. Selain itu beliau juga aktif memberikan kuliah arsitektur di kampus ITB. Bahkan hasil pengembangan penelitian dari dunia kampus digunakan sebagai bahan pengembangan desain yang diterapkan oleh Urbane. Oleh karena itu, beliau mengatakan bahwa dunia akademisi dan dunia praktek adalah dua hal yang tidak dapat dipisahkan. Karena praktisi memerlukan pengembangan keilmuan dari dunia kampus untuk meng-update karya-karya mereka, demikain juga dunia kampus memerlukan para praktisi untuk meng-create keilmuan mereka dalam wujud nyata.

\subsection{Bagaimana Seharusnya Pendidikan Arsitektur?}

Penjelasan tentang bagaimana seharusnya pendidikan arsitektur ditegaskan oleh Mangunwijaya (1992) yang mengatakan bahwa dalam ber-arsitektur hendaknya seorang arsitek dibekali dengan pemahaman tentang dasar-dasar yang dapat dipertanggungjawabkan, karena kegiatan ber-arsitektur bisa diartikan sebagai proses berbahasa, sehingga perlu bekal keilmuan dan tanggungjawab dalam penggunaannya. Disamping itu, Mangunwijaya (dalam Pangarsa, 2008) juga menjelaskan bagaimana cara belajar dan mengajarkan arsitektur, yaitu dengan pengamatan langsung objek arsitektur dengan cara pengamatan "di hadapan" atau "di dalam" arsitektur tersebut.

Proses pembelajaran ini sangat penting, karena memahami tentang ruang arsitektur tidak bisa hanya dilakukan di dalam kelas. Oleh karena itu, Eko Prawoto (dalam Pangarsa 2008) mengatakan dalam kutipan bahwa "Mereka yang belajar arsitektur lebih baik bila diajak untuk mengalami sensasi ruang secara langsung. Tak cukup mengajar dengan hanya memperlihatkan gambar-gambar, seberapapun jumlahnya". Dalam hal ini, arsitektur merupakan satu kesatuan kenyataan hidup yang terwujud dalam satu jalinan yang terpadu. Dengan demikian tidak bisa memahami dan mempelajari arsitektur hanya melalui buku garing saja, akan tetapi sangat diperlukan buku teles untuk memahami fenomena secara langsung.

Keterkaitan antara arsitektur dengan manusia sebagai subjek pengamat dan penilai, menguatkan penjelasan Ballantyne (2002: 12) bahwa sebuah bangunan dapat disebut sebagai arsitektur, tergantung dari apa yang kita rasakan terhadap bangunan tersebut. Jadi dalam menilai dan mengamati arsitektur tidak bisa hanya dilakukan dalam bidang dua dimensi saja, karena pelajaran sesungguhnya adalah ruang yang dinanunginya. Dalam hal ini, arsitektur bahkan bisa 
menjadi semacam pemberitahuan atau gambaran dari ruang yang sesungguhnya dapat dirasakan. Pengertian ini juga dijelaskan oleh Herzberger dalam (Laurens, 2004) bahwa pemahaman seseorang akan suatu objek atau lingkungan, berkaitan dengan kualitas emosional seseorang terhadap objek atau lingkungan tersebut. Hal ini menunjukkan antara arsitektur dan manusia memiliki kerkaitan yang sangat erat. Oleh karena itu, dalam mempelajari arsitektur tidak bisa hanya dikaitkan dengan wujud fisik saja yang berbicara. Dengan demikian, perlu adanya hubungan yang kuat antara dunia kampus sebagai proses pembinaan calon arsitek dengan dunia praktisi sebagai bahan pembelajaran utama dalam dunia arsitektur.

Dalam hal ini, Jurusan Arsitektur Fakultas Teknik Universitas Brawijaya Malang telah menjadi pioneer untuk mewujudkan bridging dalam pengajaran arsitektur tersebut. Langkah ini sudah dimulai sejak akhir bulan April dan akan berlangsung tiap bulan, dengan mendatangkan 'great master' dunia arsitektur dalam upaya berbagai pengalaman dan proses desain untuk dirumuskan sebagai metode desain dalam proses pengajaran. Pengembangan dari program ini nantinya juga akan mengarah pada metode atelier (bengkel) yang pernah diterapkan di Beaux-Arts, karena metode ini telah menghasilkan banyak arsitek berkualitas dalam taraf dunia sampai saat ini.

\section{Gambaran Tentang Dunia Arsitektur Kini}

\subsection{Belajar Arsitektur dari pengalaman para Arsitek}

Kecenderungan atau tren kini telah melanda manusia dari berbagai segi kehidupan, mulai dari pemilihan jenis pangan, sandang dan juga papan sebagai kebutuhan primer manusia, bahkan sampai berbagai kebutuhan lainnya yang sifatnya hanya sebagai pendukung. Kecenderungan tersebut selalu diikuti oleh hampir semua produsen sebagai penyuplai kebutuhan-kebutuhan tersebut, tidak terkecuali arsitektur. Perkembangan arsitektur dari waktu ke waktu juga selalu mengikuti perkembangan tren atau selera masyarakat. Akan tetapi, sebagai seorang arsitek tentu saja dasar yang digunakan bukan hanya sekedar mengikuti tren atau selera masyarakat saja, akan tetapi paradigma dari desain itu juga harus terlihat dari hasil karyanya. Hal ini berbeda dengan kecenderungan atau tren, karena paradigma merupakan suatu pemikiran yang mendasari ide-ide untuk diwujudkan kemudian. Melalui paradigma inilah seorang arsitek bisa memainkan perannya dalam mengubah kelompok masyarakat untuk menuju ke arah yang lebih baik atau bahkan sebaliknya.

Perkembangan teknologi saat ini juga ikut mewarnai hampir semua segi kehidupan. Kemudahan yang didapat dengan bantuan teknologi juga ikut mempengaruhi pola pikir dan pandangan manusia. Perkembangan arsitektur yang sangat berkaitan dengan teknologi juga perlahan mulai berubah. Para arsitek yang berkecimpung di dunia praktis akhirnya juga terpengaruh oleh kemunculan paradigma-paradigma yang sangat beragam dan berkembangan dengan sangat cepat.

Perkembangan paradigma dan metode desain yang ada dalam dunia praktis arsitektur selalu bermunculan seiring dengan munculnya desain-desain baru atau hadirnya arsitek-arsitek baru dan hal ini berjalan begitu cepat. Akan tetapi, merupakan suatu hal yang sangat disayangkan ketika tidak ada bridging antara dunia kampus dan dunia praktisi, sehingga perkembangan ini kurang bisa diikuti dengan baik. Padahal seyogyanya dunia kampus harus bisa memberikan output yang lebih baik atau paling tidak bisa mengimbangi apa yang terjadi di dunia praktisi saat ini. Dengan demikian, meminjam istilahnya Eko Prawoto yang tertuang dalam Pangarsa (2008:5) bahwa mengajar arsitektur tidak cukup hanya memperlihatkan gambar-gambar saja, seberapa pun jumlahnya. Hal ini dikarenakan arsitektur bukan sesuatu yang diam, melainkan dinamis dan bahkan berkembang seiring berjalannya waktu. Oleh karena itu perkembangan dunia praktisi hendaknya diikuti dengan perkembangan dunia pendidikan melalui bridging yang selalu update informasinya.

\subsection{Komparasi Metode Desain: Bagaimana Melihat Metode Desain Dari Para Arsitek Indonesia Kini?}


Berbagai metode desain yang dijelaskan di atas menunjukkan betapa cepatnya perkembangan informasi yang terjadi di luar kampus. Dengan demikian, beragam paradigma yang mendasari metode desain tersebut juga sangat kuat dalam mewarnai metode desain yang mereka kembangkan.

Berdasarkan dari paparan para arsitek yang berasal dari berbagai latar belakang yang sangat beragam, dapat diambil suatu kesimpulan bahwa secara keseluruhan paradigma yang dibangun atau yang membangun para arsitek tersebut berasal dari kutub-kutub yang berbeda, diantaranya lebih cenderung ke satu kutub, sementara yang lain berada pada kutub yang lain. Dikotomi antara kepentingan manusia dengan keberadaan alam sudah lama muncul, sehingga keberadaan salah satunya akan mengorbankan pihak yang lain. Akan tetapi, beberapa pihak lain juga memiliki kecenderunagn yang berbeda, lantas dalam posisi manakah pendidikan arsitektur kita harus diarahkan? Bukankah setiap paradigma yang dimiliki oleh mahasiswa kita nantinya yang akan membawanya ke arah yang diinginkannya?

Dikotomi keberadaan manusia dengan alam selama ini sering digambarkan sebagai dua kutub yang saling bertolak belakang. Oleh karena itu, keberadaan alam selama ini sering terabaikan, karena kebutuhan manusia sering diidentikkan dengan penguasaannya atas alam. Jika pemahaman ini terus dilanjutkan, maka keduanya tidak dapat berdiri sejajar dan berdampingan. Beberapa arsitek seperti Mamo dan Popo Danes telah mematahkan dikotomi tersebut, dimana kebutuhan manusia bisa juga disejajarkan dengan kelestarian atau kebutuhan alam. Jika hal tersebut dapat dikaji dan dikembangkan dengan baik, maka keserasian antara manusia dengan alam dapat terjaga dengan baik. Dengan demikian, disinilah peran arsitek itu dibutuhkan, yaitu untuk memberikan paradigm baru yang mengarah pada kebaikan.

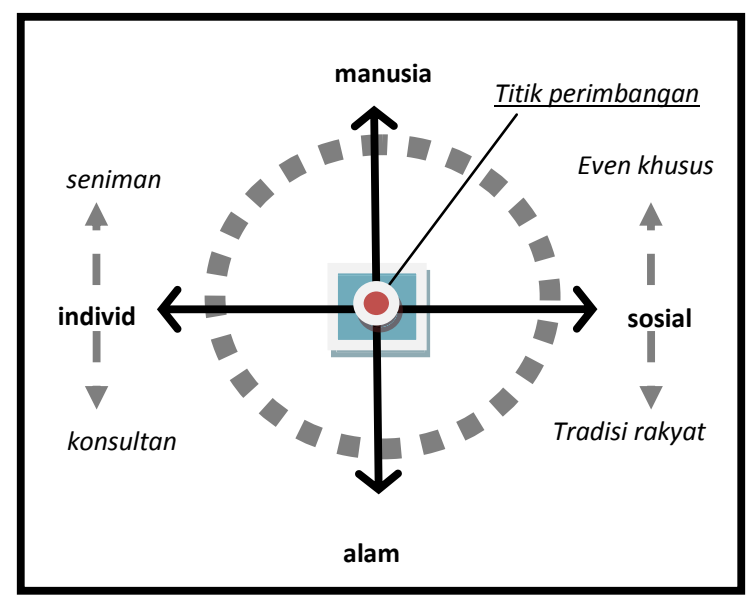

Gambar 1. Diagram kutub paradigma para arsitek Indonesia Sumber: Pangarsa, 2011 (SENVAR 12th Brawijaya University)

Selain itu, dalam dalam memposisikan diri, seorang arsitek juga dapat mendudukkan diri dalam kepentingan individu maupun social. Pemahaman akan hal ini juga selama ini dianggap sebagai dikotomi dari kutub posisi yang bersebrangan. Dengan kata lain, jika seseorang memposisikan diri untuk berada dalam lingkaran individual, maka dia tidak lagi peduli dengan social di sekitarnya. demikian juga sebaliknya, ketika seseorang terlalu asyik berada dalam lingkaran social yang dominan, maka individunya sendiri bahkan tidak diperhatikan.

Dikotomi semacam ini agaknya tidak terlalu dipusingkan oleh Budi Pradono. Melalui karyanya pori-pori house, arsitek yang selalu mengikuti trend fashion ini menunjukkan bahwa dikotomi tersebut bisa disamarkan, dengan kata lain keberadaan proyek individu juga dapat memberikan dampak terhadap perbaikan social di sekitarnya. Selain itu, Eko Prawoto juga sudah 
jauh lebih dulu berkecimpung dalam posisi ini, bahkan keterpanggilannya terlihat jelas pada saat membangun ulang Ngibikan pasca gempa Jogja 2005.

Dengan demikian, dikotomi posisi dan penempatan diri seorang arsitek bisa sangat fleksibel dan dinamis, tergantung dari paradigm apa yang dia gunakan. Memang untuk mencapai posisi pada titik perimbangan bukan suatu hal yang mudah, karena berbagai kepentingan dan kesempatan yang didapatkan oleh seorang arsitek. Hal tersebut kembali lagi pada penyataan sikap yang ditunjukkan melalui perbuatan nyata yang dia kerjakan.

\section{Rumusan Metode Desain Dalam Arsitektur}

Pendidikan arsitektur merupakan sebuah jembatan yang menghubungkan antara calon arsitek dengan para arsitek yang sudah terjun di dunia nyata. Profesi sebagai seorang arsitek memang bukan suatu hal yang mudah, karena hasil dari karya yang dia buat pasti akan menimbulkan dampak spasial yang cukup luas, serta perubahan yang cukup lama. Jika dirujuk dan dirunut kembali, maka akar dari permasalahan arsitektur di negeri kita bisa diperbaiki pangkalnya, yaitu pendidikan arsitektur kita.

Masuknya informasi yang secara besar-besaran ke dalam negeri ini, sedikit banyak telah memberikan dampak yang luar biasa terhadap arah dan tujuan dari bangsa ini, termasuk identitas. Kepudaran identitas ini bermula dari ketidakmampuan atau bahkan ketidak-mau-an dalam mengidentifikasi diri.

Berangkat dari pengetahuan dan pengalaman arsitektur nusantara, kita seharusnya bisa lebih tajam lagi dalam menggali indetitas, karena kita tinggal meneruskan dari apa yang sudah ada. Akan tetapi, keterlenaan akan maraknya eurocentricm membuat kita harus memulai lagi dari awal, karena sudah terlalu lama kita tidak menggali lagi identitas dan potensi local yang kita punya.

Melihat dari proses desain yang berkembang dan di ajarkan di kampus kita, kebanyakan juga memilikimuara yang sama, yaitu eropa dan amerika sentries. Secara umum memang bisa disamakan, akan tetapi secara khusus kita memiliki metode local yang selama ini hampir tidak tersentuh, seperti apa yang dilakukan oleh Ary Indra dengan metode intuitifnya.

Melihat dari apa yang sudah ada dan berkembang di negeri ini, seharusnya kita sudah mampu untuk merumuskan sendiri metode apa yang kita gunakan dalam berkegiatan arsitektur. Jika menurut Mamo gotongroyong adalah jiwa dari arsitektur nusantara, maka kita dapat memulainya dengan metode intuitif seperti yang dicontohkan oleh Ary Indra. Atau kita juga bisa belajar dari shape dan bentukan-bentukan nusantara seperti arsitektur kerajinan ala Paulus Mintarga. Kesemua langkah tersebut bisa dianggap sah dikala kita mau memposisikan diri dalam menjaga lokalitas dan mengembangkannya menuju kearifan lokal. Jika hal tersebut tidak mulai diberlakukan dari sekarang, maka pekerjaan rumah kita akan semakin berat di kemudian hari.

Membangun kepekaan akan kondisi dan keadaan sekitar bisa menjadi langkah awal dalam mengembangkan metode desain yang akan kita terapkan. Oleh karena itu, proses pengasahan kepekaan rasa memang harus mulai digalakkan dalam pendidikan arsitektur kita.

Semakin gencarnya arus globalisasi yang sesungguhnya adalah eurocentrism membuat kita semakin tidak mengenali potensi dan indentitas kita yang sebenarnya. Jika hal tersebut tidak kita cermati dan ditanggulangi sejak dini, maka kepekaan terhadap potensi lokal kita lama kelamaan akan semakin pudar.

Tahapan dalam menghadapi masalah ini memang tidak bisa dikerjakan secara sekaligus, karena perlu ada tahapan dalam pelaksanaannya. Meskipun tidak dipungkiri bisa saja karena kemampuan dan bakat yang dimiliki seseorang, dia bisa langsung mengamati akar permasalahannya, yaitu filosofis. 


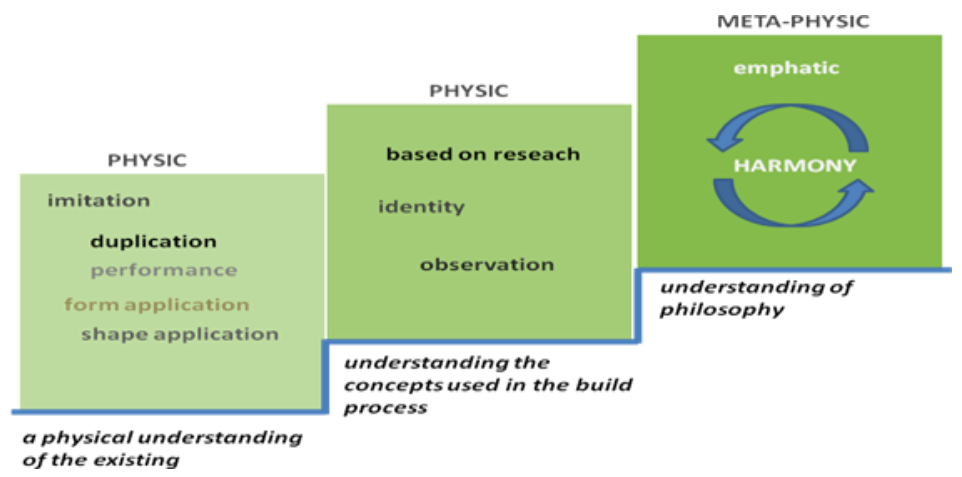

Gambar 2. Tahapan dalam proses penggalian identitas arsitektur nusantara Sumber: Ridjal, 2011 (SUSTAIN 2011, Kyoto University)

Pada tahapan ini, kita bisa mempelajari dari bentukan arsitektoniknya maupun siluetnya sebagai dasar penggalian identitas arsitektur. Akan tetapi langkah tersebut hendaknya digali lagi, terutama dari asal usul terbentuknya, serta teknologi yang mendukung terbentuknya massa tersebut. Jika hal ini dapat kita lakukan, maka konsep dasarnya sudah bisa kita gali. Lebih jauh dari itu, paradigma utama yang mendasari bentukan tersebut adalah sumber utama, jika kita mampu mengkajinya, maka DNA dari arsitektur nusantara bisa kita pegang. Jika metode desain yang kita kembangkan memiliki akar dan arah yang jelas, maka kedepan hasil desain kita juga akan memiliki identitas yang jelas.

Penggalian filosofi dalam metode desain arsitektur bukanlah hal mudah karena kebanyakan arsitek yang berkecimpung dalam hal ini merupakan seseorang dengan kepekaan rasa yang cukup tinggi. Dengan demikian, pertanyaan yang muncul adalah, bagaimana merumuskannya menjadi sebuah metode yang bisa dipahami, atau bahkan dialami oleh semua orang?

Menerjemahkan intangible factors untuk bisa dipahami secara tangible bukan hal mudah, keduanya tidak bisa dipisahkan dan tidak bisa berdiri sendiri-sendiri. Seorang arsitek harus tahu kapan dia memasukkan intuisi sebagai landasan kreatifitasnya. Penjelasan serta penggambaran dari intuisi tersebut harus bisa dipahami oleh semua pihak, terutama klien. Oleh karena itu dalam hal ini pengamatan lebih dititikberatkan pada proses desain. Jika merujuk pada penjelasan Mangunwijaya (1992), berarsitektur sesungguhnya harus menaungi unsur guna dan citra. Dalam hal ini, lebih lanjut beliau menegaskan bahwa karya arsitektur harus dapat: memberi makna; yang mengindikasikan bahwa keterpaduan antara unsur materi dan immateri tidak bisa terpisahkan; menterjemahkan atau membahasakannya ke dalam jati diri pengguna. Dengan demikian, proses kreatif bisa muncul kapan saja, bahkan pada saat proses pembangunan berlangsung, peran intuisi sangat diperlukan dalam membantu penyempurnaan desain sebagai jawaban atas permasalahan yang terjadi di lapangan. Hal ini juga diakui oleh Ary Indra dalam project Playing Housenya. Dia sangat detail dalam mengawasi setiap tahap pengerjaannya. Menurutnya desain yang berhasil adalah desain yang bisa membuat penasaran bahkan bagi arsiteknya sekalipun.

J. Christoper Jones, (1978) menjelaskan bahwa metode desain adalah salah satu upaya penyelesaian, pemecahan yang optimal terhadap sejumlah kebutuhan dalam kerangka kondisi khusus. Proses perancangan mengakibatkan perintisan perubahan-perubahan benda kesatuan manusia. Lebih lanjut Jones mengatakan, ada dua cara atau metode seorang desainer atau seorang arsitek dalam merancang sesuatu yang berkaitan dengan hasil desain. Metode tersebut yaitu metode Black Box dan Glass Box. Kenyataannya, kedua metode tersebut tidak bisa dipisahkan. Memang ada beberapa arsitek yang menonjol pada metode black box, akan tetapi juga ada ada beberapa yang berangkat dari pemikiran rasional dan pengamatan mendalam akan sesuatu. Selain 
itu, seorang arsitek harusnya mampu menjadi jembatan antara metode black box untuk dapat diterjemahkan secara rasional agar dapat dipahami oleh klien. Dengan demikian, harus terdapat sinergi antara metode black box dengan glass box. John Lang (1987) menjelaskan bahwa arsitektur terdiri dari tiga unsur yang saling berkaitan dan mempengaruhi, yaitu art, technology and human behavior, dimana ketiganya harus saling terjalin sebagai satu kesatuan sistem yang utuh. Boleh saja arsitek menggunakan dominasi black box, tetapi dalam pembangunannya harus didukung penjelasan teknologi yang rasional. Sebaliknya, untuk membuat bangunan yang memiliki taste dan identity yang berkarakter, tidak bisa hanya dibangun dengan rasional struktur dan konstruksi bangunan yang baku, akan tetapi perlu juga sentuhan art dalam suatu karya arsitektur.

Pada tahap pembentukan konsep, kedua metode ini selalu berjalan beriringan. Budi Pradono menjelaskan bahwa melalui programming dan diagramming metode desainnya dibentuk untuk mengawali proses desainnya. Meskipun secara sekilas hal ini terlihat sangat rasional, akan tetapi dalam pendekatannya hal ini sangat membutuhkan intuisi dan kepekaan rasa untuk memperoleh data dan mengolahnya bahkan sampai pada tahap pengambilan keputusan dari proses ini, peran intuisi tidak bisa diabaikan. Demikian juga pada metode desain yang dilakukan oleh arsitek lain, seperti Paulus Mintarga dengan project Remah House-nya, dimana secara sekilas peran intuitif berperan sangat dominan, akan tetapi pada proses pelaksanaannya, pengetahuannya akan material dan struktur bangunan sangat berperan untuk merasionalkan desainnya menjadi sebuah bangunan. Oleh karena itu, kedua hal ini tidak bisa saling terpisah dalam proses pembentukan konsep desain. Secara gamblang Ary Indra menjelaskan bahwa beberapa tahapan memang diperlukan bagi seorang arsitek untuk merumuskan konsep desain untuk mewujudkan sebuah arsitektur yang benar, akan tetapi peran intuisi sangat penting untuk membuat sebuah arsitektur menjadi pener atau bijak.

Dalam proses desain dan perumusan konsep, peran arsitek cukup dominan, akan tetapi hal tersebut bukanlah satu-satunya sumber dari konsep desain. Terdapat 3 (tiga) pihak yang turut berperan dalam penyusunan konsep desain, yaitu: arsitek, klien (user/ pengguna bangunan) dan tukang (pihak yang terlibat langsung di lapangan. Selain arsitek itu sendiri, terdapat klien atau user yang terlibat dalam penggunaan bangunan. Dalam hal ini user bukan hanya pemilik atau penghuni bangunan, akan tetapi semua pihak yang ikut terlibat dan menanggung segala akibatnya setelah bangunan itu berdiri, seperti tetangga sekitar, pejalan kaki atau orang yang lewat dan ikut menyaksikan keberadaan bangunan tersebut, bahkan tanaman dan lingkungan sekitar dimana bangunan tersebut berada.

Peran klien sudah tentu sangat mewarnai proses konsep desain itu sendiri, demikian juga pengguna bangunan, karena mereka akan terlibat langsung dengan keberadaan bangunan. Selain itu awal mula project itu muncul juga berdasarkan permintaan dan keingingan user. Oleh karena itu, harapan dan keinginan user harus tertuang dalam konsep desain yang dibuat oleh arsitek.

Keberadaan bangunan di suatu site secara langsung ataupun tidak akan sangat berdampak terhadap lingkungan sekitarnya, oleh karena itu selain mewadahi keinginan dan harapan klien, seorang arsitek juga harus peka terhadap keinginan dan harapan lingkungan sekitar akan keberadaan desain bangunannya kelak. Jika Budi Pradono mewadahi aktivitas sosial masyarakat sekitarnya melalui Pori-pori House, seperti yang dilakukan oleh Paulus Mintarga dengan Remah House. Popo Danes justru lebih menekankan masyarakat alam sebagai klien keduanya yang harus diperhatikan keberadaannya. Hal senada juga diungkapkan oleh Adi Purnomo dengan keterpanggilannya untuk menghijaukan lingkungan melalui prinsip gotong-royong. Hal senada juga dilakukan oleh Paulus Mintarga melalui Rumah Turi.

Setelah semua tahapan dalam penyusunan konsep dan gambar perancangan sudah didapatkan, maka langkah selanjutnya yang paling penting adalah menuangkan apa yang ada di atas kerta untuk diterapkan di lokasi bangunan. Pada tahapan ini, peran tukang sebagai ujung tombak desain arsitektur menjadi sangat penting dan mengambil porsi yang sangat dominan. Oleh karena itu, keterlibatan tukang dalam menuangkan desain sangat besar. Meskipun secara teori tahap 
penyusunan konsep desain sudah selesai, akan tetapi praktiknya hal tersebut masih setengah jalan, karena berbagai kemungkinan masih sangat mungkin akan terjadi di lapangan. Paulus Mintarga melalui Remah House telah menunjukkan betapa peran tukang sangat dominan dalam membantu merumuskan konsep desain pada saat bangunan tersebut dibangun. Demikian juga dengan Budi Pradono melalui kindah Office dan Bamboo House yang sangat menggantungkan pada kemampuan dan keahlian tukang dalam mengolah material yang digunakannya. Oleh karena itu, Mangunwijaya (1992) menjelaskan dalam proses merumuskan konsep desain, pendekatan konseptual jauh lebih dominan dari pada manerism. Secara umum keragaman bangunan dengan beragam klien akan merumuskan metode desain yang beragam pula, akan tetapi secara garis besar kesemuanya memiliki peran yang sama, yaitu keterlibatan berbagai pihak dalam penyusunan konsep desain.

\section{Simpulan}

Dalam memahami metode desain, seorang arsitek tak terlepas dari paradigma yang telah dibangunnya. Pemahaman akan hal ini akan sangat mempengaruhi metode merancang atau metode membangun yang dilakukannya. Secara garis besar, metode merancang arsitektur tidak bisa dipisahkan dengan metode membangunnya, karena kedua hal tersebut saling terkait dan berurutan sampai terwujudnya suatu karya arsitektur. Sebagian karya arsitek memang berawal dari konsep desain yang dituangkan melalui sketsa-sketsa, akan tetapi beberapa diantaranya juga muncul justru pada saat tahap pelaksanaan mulai dilakukan.

Dalam merumuskan metode desain ini, terdapat dua metode dasar yang bekerja secara bersamaan, yaitu black box dan glass box. Merumuskan metode melalui tahapan rasionalisat bertujuan untuk mendapatkan benarnya suatu karya arsitektur, akan tetapi pener-nya suatu karya arsitektur diperlukan kepekaan rasa dan intuisi untuk mengambil keputusannya. Selain merumuskan konsep desain, metode desain yang terpenting adalah justru dengan melibatkan semua pihak terkait dalam proses desain dari awal hingga akhir, yaitu: arsitek, klien (user) dan tukang (pihak yang terlibat dalam pembangunan). Kesemua pihak tersebut harus terlibat secara bersama-sama berdasarkan porsinya masing-masing.

\section{Daftar Pustaka}

Alexander, C (1964), Notes And the Synthesis of Form, Havard University Press, Cambridge, Massachusetts.

Ballantyne, Andrew. 2002. What is Architecture? New York: Routledge

Crowe, Norman. 1995. Nature and The Idea of A Man-Made World: An Investigation Into The Evolutionary Roots of Form and Order in the Built Environment. London: The MIT Press.

Handinoto \& Samuel Hartono. 2008. Pendidikan Sistem Studio dari Beaux-Arts ke Bauhauss, Sampai Abad 21 di Indonesia. Prosiding Seminar Nasional Pendidikan Arsitektur. Denpasar, Bali,

Jones, John Christoper. 1992. Design Methods. New York: Van Nostrand Reinhold Company

Lang, Jon. 1987. Creating Architectural Theory. New York: Van Nostrand Reinhold Company

Laurens, Joyce Marcella. 2004. Arsitektur dan Perilaku Manusia. Surabaya: Grasindo

Mangunwijaya, 1992. Wastu Citra: Pengantar ke Ilmu Budaya Bentuk Arsitektur Sendi-sendi Filsafatnya Beserta Contoh-contoh Praktis. Jakarta: Gramedia Pustaka Utama.

Pangarsa, 2008. Arsitektur untuk Kemanusiaan (Teropong Visual Culture atas Karya-karya Eko Prwoto). Surabaya: PT. Wastu Lanas Grafika

Pangarsa, Galih W. 2011. International conference SENVAR $12^{\text {th }}$ Brawijaya University, Malang. Rapoport, Amos. 1969. House Form and Culture. Englewood Cliffs, NJ, Prentice Hall

Ridjal, Abraham M. 2011. Architecture and Our Ancestors. International Conference SUSTAIN 2011, Kyoto University, Kyoto.

Snyder and Catanese, 1989, Pengantar Arsitektur, Jakarta: Erlangga 